NUSANTARA : Jurnal Ilmu Pengetahuan Sosial - Vol. 6 No 1 (2019) ( Januari - Juni )

issn online : $2550-0813$ issn cetak : 2541-657X

http://jurnal.um-tapsel.ac.id/index.php/nusantara

\title{
PENDIDIKAN POLITIK BAGI PEMILIH MILENIAL DALAM MEMAHAMI BAHAYA VOTE BROKER OLEH KPU
}

Fauziah Harnom $^{1)}$, Syahrizal' ${ }^{2}$, Tengku Rika Valentina ${ }^{3)}$

auzi.anum@gmail.com

${ }^{1)}$ Mahasiswa Pascasarjana FISIP Universitas Andalas

${ }^{2,3)}$ Pascasarjana FISIP Universitas Andalas

\begin{abstract}
Abstrak
Pemilih milenial merupakan pemilih yang besar di Indonesia. Peran mereka sangat penting dalam meningkatkan partisipasi pemilih, agar terciptanya pemilu yang berkualitas. Untuk meningkatkan minat dan pemahaman mereka tentang pemilu serta bahaya dari politik uang terutama yang dilakukan oleh broker politik. Kurangnya pemahaman pemilih milenial tentang Pemilu salah satu yang membuat politik uang berkembang di negara ini. Untuk itu perlu bagi KPU sebagai penyelenggara memberikan sosialisasi berupa pendidikan politik kepada pemilih milenial.
\end{abstract}

Kata kunci : Pemilih milenial, broker politik, politik uang, dan pendidikan politik

\section{PENDAHULUAN}

$\begin{array}{lcr}\text { Berdasarkan } & \text { hasil } & \text { evaluasi } \\ \text { pemilu Tahun } & \text { 2014, } & \text { KPU } \\ \text { mengelompokkan } & \text { tiga } & \text { jenis }\end{array}$ malpraktek yang terjadi pada pemilu 2014. Secara umum menurut Ardiles r. M. Mewoh, dkk (2014:86) terdapat tiga kategori malpraktik pemilu, yaitu: pertama, pemilu tanpa pemilu; kedua, politik uang yng diberikan kepada pemilih dan; ketiga, ditemukannya penyelenggara pemilu yang tidak berintegritas. Praktik politik uang terjadi sebagai bentuk menggunakan uang untuk memenangi pemilihan dengan membeli suara pemilih. Suara pemilih dinilai dengan sejumlah rupiah. Dengan maraknya praktik politik uang maka orang-orang yang berhasil dipilih, mereka elite-elite politik yang akan menduduki kursi legislatif terpilih bukan berdasarkan kepercayaan pemilih namun karena uang yang berbicara. Praktik politik uang cenderung berbanding paralel dengan kekuasaan yang korup dan membangun relasi politik menjadi transaksional serta pragmatis. Politik uang pada akhirnya dapat membunuh sistem demokrasi.
Dalam rangka meningkatkan kualitas pemilu 2019, sudah selayaknya bagi penyelenggara pemilu memberikan pendidikan politik tentang bahaya politik uang kepada generasi muda. Kita tidak bisa mengesampingkan fenomena politik uang yang terjadi di Indonesia. Berdasarkan data yang di dapat dari acch.kpk.go.id pada tahun 2018 Komisi Pemberantasan Korupsi (KPK) telah menetapkan kasus korupsi yang terdiri atas 127 kasus penyelidikan, 126 kasus penyidikan, 101 kasus penuntunan, 75 kasus inkracht (berkekuatan hukum tetap), dan 80 kasus yang telah di eksekusi. Seharusnya melalui berita ini memberikan kesadaran kepada masyarakat terutama generasi muda akan pentingnya memilih secara rasional dan tidak terbuai dengan politik uang.

Vote broker atau yang bisa disebut orang/kelompok orang yang mewakili kandidat untuk membagikan uang/barang, orang/kelompok ini tidak terdaftar sebagai tim sukses di Komisi Pemilihan Umum (KPU). Sekelompok orang yang banyak bermunculan ketika pemilihan umum (pemilu) 
NUSANTARA : Jurnal Ilmu Pengetahuan Sosial - Vol. 6 No 1 (2019) (Januari - Juni )

issn online : $2550-0813$ issn cetak : $2541-657 \mathrm{X}$

http://jurnal.um-tapsel.ac.id/index.php/nusantara

dilaksanakan. Tindakan ini merupakan salah satu bentuk dari malpraktek pemilu.

Vote broker merupakan salah satu bentuk malpraktek dalam pemilu, merupakan tindakan yang dilakukan tidak berdasarkan aturan yang berlaku. Dalam hal penyelenggara pemilu, malpraktek bisa terjadi karena penyelenggara tidak mengetahui aturannya atau bisa disebabkan waktu yang sedikit, sehingga proses yang seharusnya panjang dibuat menjadi singkat. Sedangkan bagi peserta pemilu, malpraktek dilakukan untuk mendapatkan suara dari pemilih dengan tindakan-tindakan yang tidak ada dalam aturan pemilu bagi keuntungan pribadi mereka.

Esensi pemilu menurut Ramlan Subakti (2014) sebenarnya sederhana, yakni kedaulatan rakyat dikelola melalui pemungutan suara, sebagai cara untuk menentukan kursi jabatan publik dalam penyelenggaraan pemerintahan negara. Dalam praktiknya, proses ini berjalan cukup rumit dan bermacam-macam, termasuk tentang bagaimana rakyat dijamin hak pilihnya, bagaimana pemungutan suara dilakukan, bagaimana suara dihitung dan ditetapkan, bagaimana suara dikonversi menjadi kursi, dan bagaimana mengelola konflik selama proses ini berlangsung.

Dalam tahap pewujudan kedaulatan rakyat terdapat sejumlah aspek yang menentukan karakter dan kualitas sebuah pemilu, termasuk pendataan warga negara untuk menjadi pemilih, proses penjaminan hak para pemilih untuk dapat menggunakan hak pilihnya secara baik, pembentukan badan penyelenggara pemilu, penyiapan peraturan pelaksanaan pemilu, dan sebagainya. Sehingga dari hal ini bisa menimbulkan malpraktek pemilu, Sarah Birch dalam penelitian yang dilakukannya mengklarifikasikan malpraktik pemilu menjadi tiga jenis, yakni: manipulasi terhadap peraturan perundang-undangan pemilu (manipulation of election legal framework), manipulasi pilihan pemilih yang bertujuan untuk mengarahkan atau mengubah pilihan pemilih dengan cara-cara yang manipulatif (manipulation of vote choises), terakhir manipulasi terhadap proses pemungutan dan penghitungan suara hingga pemilu berakhir (manipulation of electoral administration) (dalam Ramlan Surbakti dkk,2014).

Sedangkan malpraktek yang dilakukan oleh peserta pemilu pada tahapan masa kampanye berupa manipulasi pilihan pemilih yang bertujuan untuk mengarahkan atau mengubah pilihan pemilih dengan cara-cara yang manipulatif. Di Indonesia sering dilakukan dengan cara vote buying dan dilakukan oleh kelompok vote broker. Semenjak bergulirnya masa reformasi di Indonesia, maka terjadi perubahan dibeberapa sistem politik dan birokrasi. Tak ketinggalan pada sistem pemilu di Indonesia. Dari Tahun 2004, sistem pemilu Indonesia yang awalnya proposional tertutup menjadi proporsional daftar terbuka. Sistem proporsional terbuka ini memberikan peluang bagi siapa saja untuk ikut berpartisipasi menjadi wakil rakyat di parlemen. Sistem proporsional terbuka sebenarnya lebih demokratis karena dengan sistem ini memberikan peluang bagi setiap orang untuk mendapatkan hak pilihnya. Namun, ketika sistem ini diterapkan menjadikan praktek politik uang yang masif. Sistem proporsional terbuka dilakukan dengan pemilih bisa 
NUSANTARA : Jurnal Ilmu Pengetahuan Sosial - Vol. 6 No 1 (2019) ( Januari - Juni )

issn online : $2550-0813$ issn cetak : 2541-657X

http://jurnal.um-tapsel.ac.id/index.php/nusantara

langsung memilih calon, sehingga suara yang didapat langsung didstribusikan kepada calon tersebut. Banyak dari calon-calon ini yang ingin mendapatkan suara secara instan, sehingga mereka melakukan pembelian suara kepada pemilih.

Susan Stokes (dalam Edward Aspinall, 2014:547) dalam buku magisterial yang ditulisnya, semenjak abad ke-19 di Inggris, menjelaskan bahwa broker politik ini memiliki sistem parasit dan saling mengkhianati antara mereka. Kandidat tidak memiliki pilihan lain selain bergantung pada broker lokal yang memang dekat dengan pemilih di daerah pilihan tersebut.

Salah satu hal yang bisa dilakukan adalah dengan memberikan pendidikan politik bagi pemilih. Tentu bukanlah hal mudah dalam mempengaruhi atau memberikan pemahaman politik terhadap masyarakat (rakyat). Ada beberapa faktor dominan yang dapat mempengaruhi pemahaman politik masyarakat, yaitu faktor pendidikan, faktor lingkungan, faktor jenis kelamin, faktor keturunan sampai faktor mata pencarian. Jika salah satu dari kelima faktor tesebut dapat berperan aktif dalam masyarakat, maka akan mempengaruhi pemahaman masyarakat terhadap politik. Dari segi budaya politik juga memiliki peran besar dalam pemahaman masyarakat terhadap politik, yaitu seperti dikemukakan oleh Gabriel Al Almond dan Sidney Verba (1990:21) yang mengatakan bahwa budaya politik adalah sikap orientasi warga negara terhadap sistem politik dan aneka ragam bagiannya, dan sikap terhadap

peranan warga negara didalam sistem itu. Sedangkan menurut Mochtar Mas'oed dan Colin Mac Andrew
(1986:41) mengatakan budaya politik adalah sikap dan orientasi warga suatu negara terhadap kehidupan pemerintahan negara dan politiknya.(dalam Asmika Rahman,2014:45)

Salah satu kelompok pemilih yang penting untuk diberikan pendidikan politik adalah pemilih milenial ${ }^{1}$. Menurut Komisioner KPU Pramono Ubaid Tanthowi yang dikutip dari berita republika.go.id menyebut pemilih milenial menjadi penentu siapa pemimpin kedepannya dan ke mana arah bangsa akan dibangun. Pramono menyebut pemilih milenial ini menurut data KPU, jumlahnya mencapai 70-80 juta dari sekitar 193 juta pemilih. Artinya mencapai 35-40 persen yang memiliki pengaruh besar terhadap hasil pemilu. Dengan adanya dukungan dari pemilih milenial dan memilih secara rasional, maka legitimasi pemerintan dari hasil

\footnotetext{
${ }^{1}$ Generasi Y dikenal dengan sebutan generasi millenial atau milenium. Ungkapan generasi Y mulai dipakai pada editorial koran besar Amerika Serikat pada Agustus 1993. Generasi ini banyak menggunakan teknologi komunikasi instan seperti email, SMS, instant messaging dan media sosial seperti facebook dan twitter, dengan kata lain generasi $\mathrm{Y}$ adalah generasi yang tumbuh pada era internet booming (Lyons, 2004). Lebih lanjut (Lyons, 2004) mengungkapkan ciri - ciri dari generasi $\mathrm{Y}$ adalah: karakteristik masing-masing individu berbeda, tergantung dimana ia dibesarkan, strata ekonomi, dan sosial keluarganya, pola komunikasinya sangat terbuka dibanding generasi-generasi sebelumnya, pemakai media sosial yang fanatik dan kehidupannya sangat terpengaruh dengan perkembangan teknologi, lebih terbuka dengan pandangan politik dan ekonomi, sehingga mereka terlihat sangat reaktif terhadap perubahan lingkungan yang terjadi di sekelilingnya, memiliki perhatian yang lebih terhadap kekayaan. (Dalam Yanuar Surya Putra,2016:125)
} 
NUSANTARA : Jurnal Ilmu Pengetahuan Sosial - Vol. 6 No 1 (2019) ( Januari - Juni )

issn online : $2550-0813$ issn cetak : 2541-657X

http://jurnal.um-tapsel.ac.id/index.php/nusantara

pemilu 2019 akan menjadi lebih baik dan kuat.

Melalui tulisan ini, penulis ingin memberikan penjabaran tentang manfaat pendidikan politik bagi pemilih milenial dalam memahami bahaya vote broker. Tujuan penulisan ini adalah agar pemilih milenial memahami tentang bahaya dari politik uang, sehingga dengan adanya pemahaman yang mereka miliki maka mereka sadar untuk memilih, serta tujuan dari memilih karena memilih dengan tepat akan menjamin masa depan rakyat Indonesia untuk 5 tahun ke depan. Dengan adanya pendidikan politik, pemilih milenial ini bisa menunjukan partisipasi yang baik dalam pemilu, bukan sekedar seremoni saja namun memahami tujuan dari pemilu tersebut.

\section{Metode Penelitian}

Dalam penelitian ini penulis menggunakan metode studi kepustakaan. Dalam setiap penilitian studi kepustakaan sangat diperlukan, namun dalam studi lapangan riset kepustakaan hanya digunakan sebagai langkah awal untuk menyiapkan penelitian. Sedangkan dalam studi pustaka, penelusuran pustaka lebih kepada pemanfaatan sumber perpustakaan untuk memperolah data untuk penelitian. Tegasnya studi pustaka membatasi kegiatannya hanya pada bahan-bahan koleksi perpustakaan saja tanpa memerlukan riset lapangan.

Ada tiga alasan kenapa peneliti menggunakan studi pustaka dalam risetnya. Pertama, karena persoalan penelitian tersebut hanya bisa dijawab lewat penelitian pustaka dan sebaliknya tidak mungkin mengharapkan riset lapangan. Kedua, studi pustaka diperlukan sebagai salah satu tahap tersendiri, yaitu studi pendahuluan untuk memahami lebih dalam gejala baru yang tengah berkembang di lapangan atau dalam masyarakat. Ketiga, data pustaka menjadi pilihan yang penting untuk menjawab persoalan penelitian. Dari data empirik atau informasi yang telah dikumpulkan orang lain, baik berupa laporan hasil penelitian, atau laporanlaporan resmi, buku-buku yang tersimpan diperpustakaan tetap dapat dipergunakan oleh periset kepustakaan. Dalam kasus tertentu data lapangan diperkirakan tidak cukup signifikan untuk menjawab pertanyaan penilitian yang akan dilakukan.(Mestika Zed, 2004:2)

\section{PEMBAHASAN}

\section{Vote Broker}

Istilah politik uang telah secara luas digunakan untuk menggambarkan praktik-praktik pembagian uang kepada pemilih oleh kandidat, memberikan barang serta menyuap para pejabat penyelenggara pemilu, hal ini telah berlangsung sejak demokratisasi di Indonesia bermula pada akhir 1990-an. Di awal reformasi, orang seringkali menggambarkan praktik uang di kalangan lembaga legislatif sebagai salah satu bentuk praktik politik uang. Istilah yang sama juga digunakan untuk menggambarkan praktik pembelian suara dalam konteks kongres partai politik, maupun praktik korupsi politik yang lebih bersifat umum seperti keterlibatan anggota lembaga legislatif dalam penggelapan uang dari proyek pemerintah. (Andri Rusta,2015:3)

Setiap bentuk korupsi dalam proses pemilihan selalu diidentikan dengan politik uang. Hal tersebut menurut Daniel Bumke, karena selama ini tidak ada definisi yang jelas. Politik uang digunakan untuk menerangkan semua jenis praktek dan 
NUSANTARA : Jurnal Ilmu Pengetahuan Sosial - Vol. 6 No 1 (2019) (Januari - Juni )

issn online : $2550-0813$ issn cetak : $2541-657 \mathrm{X}$

http://jurnal.um-tapsel.ac.id/index.php/nusantara

perilaku korupsi dalam pemilu. Mulai dari korupsi politik hingga klientelisme dan dari membeli suara (vote buying) hingga kecurangan. Bumke secara umum mengategorikan politik uang dalam tiga dimensi yaitu, vote buying, vote broker, dan korupsi politik. Vote buying merupakan pertukaran barang, jasa, atau uang dengan suara dalam pemilihan umum dan orang yang mewakili kandidat/partai untuk membeli suara adalah vote broker. Sedangkan korupsi politik adalah segala bentuk suap kepada politisi dalam rangka mendapatkan kebijakan yang menguntungkan atau keuntungan lainnya. ( Ade Irawan,dkk,2014:77)

$$
\text { Menurut Syarif Hidayat }
$$

praktek politik uang dimulai dari proses nominasi kandidat, selama masa kampanye, hingga hari ' $\mathrm{H}$ ' pemilihan ketika suara dihitung. Ada dua jenis politik uang. Pertama, secara langsung dengan memberikan uang kepada pemilih. Kedua, secara tidak langsung dengan memberikan berbagai barang yang memiliki nilai guna dan nilai tukar yang tinggi. Walau belum ada definisi yang jelas berkaitan dengan politik uang. Tapi setidaknya ada empat hal penting yang harus diperhatikan berkaitan dengan politik uang. Pertama, vote buying atau membeli suara. Kedua, vote broker atau orang/kelompok orang yang mewakili kandidat untuk membagikan uang/barang. Ketiga, uang atau barang yang akan dipertukarkan dengan suara. Keempat, pemilih dan penyelenggara pemilihan yang menjadi sasaran politik uang. ( Ade Irawan,dkk,2014:78)

Proses barter uang atau barang dengan pemilih/penyelenggara biasanya tidak melibatkan kandidat secara langsung. Selain mudah diketahui oleh lawan politik, resikonya tinggi seperti dianulir sebagai peserta pemilihan. Karena itu, kandidat membentuk tim yang berperan dalam menentukan strategi pemenangan termasuk didalamnya melakukan politik uang sebagai bagian dari strategi untuk memenangkan persaingan. Perseorangan atau kelompok orang yang berperan untuk mewakili kandidat dalam membagikan uang atau barang dalam rangka mempengaruhi pemilih dan penyelenggara sering disebut sebagai vote broker. Vote broker biasanya merupakan bagian dari tim sukses. Tapi umumnya mereka tidak tercatat sebagai tim formal yang dilaporkan kepada komisi pemilihan umum (KPU). (Ade Irawan,dkk, 2014:81)

Edward Aspinall, membedakan tipologi broker yng dibedakan atas dasar motivasi mereka untuk bekerja dengan kandidat. Activist broker, yaitu kesetiaan yang dimiliki seseorang sehingga memotivasinya bekerja secara independent dan terhindar dari patronase. Clientelist brokers and opportunist brokers, mereka yang bekerja atas dasar motivasi untuk mendapatkan keuntungan materi. Clientelist brokers lebih kepada membangun hubungan jangka panjang dengan kandidat, sedangkan opportunist brokers lebih tertarik untuk segera mendapatkan hasil. Kemudian ketiga sejauh mana predasi dan pembelotan terjadi oleh broker tersebut.

Edward Aspinall membagi beberapa bentuk politik uang dan patronase yakni (1) pembelian suara (vote buying) dimaknai sebagai distribusi pembayaran uang tunai/barang dari kandidat kepada pemilih secara sistematis beberapa hari menjelang pemilu yang disertai dengan harapan yang implisit bahwa para penerima akan membalasnya 
NUSANTARA : Jurnal Ilmu Pengetahuan Sosial - Vol. 6 No 1 (2019) (Januari - Juni )

issn online : $2550-0813$ issn cetak : 2541-657X

http://jurnal.um-tapsel.ac.id/index.php/nusantara

dengan memberikan suaranya bagi si pemberi. (2) pemberian-pemberian pribadi (individual gifts) pemberian dilakukan biasanya pada saat kandidat bertemu dengan pemilih, baik ketika melakukan kunjungan ke rumahrumah atau pada saat kampanye. (3) pelayanan dan aktivitas (services and activities) seperti pemberian uang tunai dan materi lainnya, kandidat seringkali menyediakan atau membiayai beragam aktivitas dan pelayanan untuk pemilih. (4) barangbarang kelompok (club goods) praktik yang diberikan lebih untuk keuntungan bersama bagi kelompok sosial tertentu ketimbang bagi keuntungan individual. (5) proyekproyek gentong babi (pork barrel projects) proyek-proyek pemerintah yang ditujukan untuk wilayah geografis tertentu dengan tujuan kepada publik dan didanai dengan dana publik dengan harapan publik akan memberikan dukungan politik kepada kandidat tertentu. (dalam Andri Rusta,2015:3)

\section{Pemahaman Pendidikan Politik Bagi Pemilih Milenial Akan Bahaya Vote Broker}

Banyak pemilih yang tidak memahami akan bahaya politik uang. Ini terjadi karena politik uang dilakukan secara masif dan tanpa disadari. Ketika suatu daerah akan melakukan acara dan mendapatkan sponsor dari mereka yang mencalonkan diri, ini merupakan salah satu bentuk politik uang.

Sebagai salah satu lembaga penyelenggara pemilu, KPU memiliki kewajiban untuk memberikan pendidikan politik bagi pemilih, terutama pemilih milenial yang mencapai angka 40\% dari total jumlah pemilih di Indonesia. Setiap akan diadakan pemilu, KPU akan selalu gencar melakukan sosialisasi pendidikan politik, program terbaru dari KPU dalam menyambut pemilu 2019, KPU memiliki kegiatan sosialisasi berupa KPU Goes to school, KPU Goes to Campus, serta adanya kursus kepemiluan.

Sosialisasi yang dilakukan oleh KPU Provinsi Sumatera Barat tentang KPU goes to campus lebih ditekankan kepada pengenalan terhadap wakil-wakil calon legislatif yang mencalonkan diri untuk ikut pemilu Tahun 2019. Sosialisasi ini disampaikan oleh komisioner KPU RI yaitu Bapak Viryan Aziz yang dilaksanakan di kampus Universitas Andalas Padang. Pada Acara goes to campus yang berlangsung hari MInggu tanggal 9 Desember 2019 sebanyak 300 mahasiswa yang dominan berasal dari luar kota Padang dan luar Sumbar. Inti dari sosialisasi yang dilakukan oleh Bapak Viryan Aziz adalah agar mahasiswa sadar dengan adanya pemilu 2019 merupakan salah satu cara mewujudkan cita cita pendiri bangsa.Mahasiswa yang hadir pada acara ini berlangsung tergolong pemilih milineal, mereka diingatkan untuk menjadi pemilih yang cerdas dan berkualitas. Sebagai mahasiswa yang berpikir dan memiliki intelektual dan paham dengan teknologi saat ini, agar mereka memilih secara rasional, jangan lagi mau memilih karena dibayar. Disamping itu dalam sosialisasi ini juga dijelaskan tentang jumlah kursi dan dapil pada pemilu 2019 sebanyak 20.258 kursi dengan 2.592 dapil, menjelaskan contoh Surat Suara yang digunakan. Disamping itu pemilih milenial ini juga diingatkan apa mereka sudah terdaftar di daftar pemilih tetap, agar mereka bisa memilih pada hari $\mathrm{H}$ pencoblosan. 
NUSANTARA : Jurnal Ilmu Pengetahuan Sosial - Vol. 6 No 1 (2019) (Januari - Juni )

issn online : $2550-0813$ issn cetak : $2541-657 \mathrm{X}$

http://jurnal.um-tapsel.ac.id/index.php/nusantara

Kegiatan KPU Goes To

Campus juga dilakukan di Universitas Hasanuddin (Unhas) Makassar. Kegiatan ini dilaksankan pada hari Rabu tanggal 24 Oktober 2018 yang diikuti oleh mahasiswa dan mahasiswi Unhas dimana tema yang diangkat adalah pemilih muda berdaulat negara kuat. Bahasan sosialisasi yang disampaikan oleh Ketua KPU Provinsi Sulawesi Selatan Misnah M Attas lebih menenkankan pada apa itu pemilu, asas pemilu, penyelenggaranya, termasuk sosialisasi pemilu serentak 2019 memilih Anggota DPR, Anggota DPRD Provinsi, Anggota DPRD Kab/Kota, Anggota DPD, Presiden dan Wakil Presiden. Salah satu hal penting disampaikan adalah agar mahasiswa tidak terlibat pada kegiatan yang melanggar aturan pemilu dan mahasiswa sebagai manusia intelektual harus ikut melakukan pengawasan secara mandiri, sehingga bisa dipastikan pemilu ini berjalan dengan baik. Disamping itu sebagai pemilih, mahasiwa haruslah menyadari untuk tidak mudah terpengaruh dengan kampanye hitam, intimidasi, politik uang, pemalsuan dokumen, penggunaan fasilitas negara dan kampanye diluar jadwal.

Sedangkan untuk KPU goes to school, dilakasanakan pada hari Jumat tanggal 31 Agustus 2018, kegiatan ini dilakukan oleh KPU Kabupaten Badung dengan dihadiri lebih dari 150 orang siswa siwsi SMK PGRI 2 Badung di . Dalam sosialisasi ini yang menjadi pemateri adalah Anggota KPU Kabupaten Badung Divisi Sosialisasi, I Wayan Artana Dana yang menyampaikan beberapa materi seperti pemahaman tentang Pemilu dan Jenis Pemilu, serta Anggota KPU Badung Divisi Keuangan Umum dan Logistik, Ni Luh Nesia Padma Gandi tentang pentinggnya menggunakan hak pilih dan menjadi penyelenggara yang berintegritas.

Kemudian KPU Provinsi

Kalimantan Selatan juga
melaksanakan KPU goes to school ke Sekolah SMAN 7 Banjarmasin pada tanggal 23 November 2018 orang. Inti dari sosialisasi yang dilakukan ini adalah pentingnya partisipasi pemilih dalam pemilihan umum. Komisioner KPU Provinsi Kalimantan Selatan Masyithah, memberikan arahan pada pemilih pemula untuk tidak tergoda dengan iming-iming uang dari pasangan calon. Pemilih harus menjadi pemilih yang cerdas agar kualitas pemilu terus ada.

Bentuk sosialisasi lainnya yang dilakukan oleh KPU adalah kursus kepemiluan. Pentingnya kesadaran untuk berpartisipasi oleh masyarakat dalam pemilu, KPU Kota Bukittinggi menyelenggarakan program pendidikan pemilih dalam bentuk kursus pemilu. Kursus ini dilaksanakan selama lima hari yang diikuti 100 peserta berasal dari mahasiswa serta masyarakat umum yang ada di Kota Bukittinggi. Dalam lima hari ini KPU Kota Bukittinggi menyampaikan tentang pemilu, tahapan pemilu, penyelenggara pemilu, serta politik uang. Ketua KPU Kota Bukittinggi menyampaikan bahwa kursus pemilu adalah cara lembaganya menyosialisasikan segala hal tentang kepemiluan kepada masyarakat. Menurut dia, KPU juga butuh dukungan masyarakat untuk menyampaikan informasi kepemiluan kepada masyarakat lain yang ada dilingkungannya. Salah satu hal yang paling ditekankan pada sosialisasi pemilu adalah bagaimana mengajak 
NUSANTARA : Jurnal Ilmu Pengetahuan Sosial - Vol. 6 No 1 (2019) (Januari - Juni )

issn online : $2550-0813$ issn cetak : $2541-657 \mathrm{X}$

http://jurnal.um-tapsel.ac.id/index.php/nusantara

peserta menjauhi politik uang (money politic) dalam pemilu.

Dari paparan diatas, apa yang dilakukan oleh KPU sesuai dengan penjelasan dari Michael Rush dan Phillip Althoff (2008:25), mereka menjalaskan tentang sosialisasi politik merupakan proses untuk memperkenalkan sistem politik kepada seseorang atau sekelompok orang. Dari sosialisasi yang dilakukan maka akan memunculkan sikap mereka terhadap isu-isu politik yang ada. Mereka mampu memberikan tanggapan terhadap isu-isu yang ada, sehingga bisa membedakan mana yang benar dan salah dari sebuah informasi. Dalam model yang diberikan oleh Michael Rush dan Phillip Althoff, organisasi pemerintah atau disni kita lihat peran dari KPU. KPU merupakan agen pemberi informasi bagi pemilih pemula. Proses sosialisasi tersebut akan sangat berarti bila diberikan pada umur sedini mungkin. Ini dilakukan agar proses tersebut berjalan terus. Sosialisasi merupakan kegiatan yang terus berkesinambungan, dilakukan seumur hidup dari masa anak-anak, remaja dan dewasa.

\section{KESIMPULAN}

Kegiatan sosialisasi yang dilakukan oleh KPU pada pemilih milenial hanya dilakukan ketika pemilu akan berlangsung. Materi yang disusung oleh KPU lebih banyak menjabarkan tentang masalah teknis dari pemilu, kemudian baru unsur dari politik uang diberikan. Akan tetapi, dalam memberikan materi tentang politik uang KPU tidak memiliki bahan atau modul, sehingga pemilih pemula hanya tau tentang menghindari kalau ada orang yang ingin memberikan uang dan coblos kandidat mereka. KPU tidak menjabarkan tentang bentuk dari politik uang dan bagaimana sistem itu bekerja.

Padahal menurut Edward Aspinall, pada pemilu Tahun 2014 politik uang sangat menyebar di Indonesia, ini disebabkan adanya peran makelar atau vote broker dalam pemilihan umum. Dalam artikel When Brokers Betray: Clientelism, Social Networks, and Electoral Politics in Indonesia kandidat membentuk "tim sukses” untuk mengorganisir para makelar dan memobilisasi para pemilih. Ada tiga jenis makelar ini yaitu (1) aktivis makelar, yang mendukung para kandidat berdasarkan pada politik, etnis, agama, atau komitmen lain: (2) Pelanggan makelar, yang menginginkan hubungan jangka panjang dengan kandidat atau dengan makelar-makelar yang terdahulu, dengan tujuan untuk mendapatkan imbalan dimasa depan: (3) makelar oportunis, mereka yang mencari pendapatan material jangka pendek pada saat masa kampanye.

Kemudian berdasarkan data yang didapat oleh Koordinator Jaringan Pendidikan Pemilih untuk Rakyat (JPPR) sebagaimana dikutip dari merdeka.com, ada beberapa modus yang terjadi dalam praktek vote broker yaitu pelaku atau broker membeli surat undangan pemilih yang telah datang ke tempat pemungutan suara (TPS), dengan begitu, maka pemilih yang ada dalam DPT tentu harus merelakan hak suaranya dibeli orang lain. Modus ini dinilai bertujuan untuk mencegah pemilih memberikan suara kepada lawan politik. Pemilih digiring dan menyerahkan suaranya kepada caleg yang mengordernya melalui broker 
NUSANTARA : Jurnal Ilmu Pengetahuan Sosial - Vol. 6 No 1 (2019) ( Januari - Juni )

issn online : $2550-0813$ issn cetak : $2541-657 \mathrm{X}$

http://jurnal.um-tapsel.ac.id/index.php/nusantara

tersebut. Praktik ke-dua yang dilakukan yaitu oknum yang mencoba menggiring pemilih ke TPS tertentu yang sudah dikondisikan. TPS tersebut telah dipersiapkan sedemikian rupa untuk memenangkan salah satu pihak baik individu caleg ataupun partai, yang ketiga, adanya praktik kongkalikong antara oknum, broker, atau caleg dengan Kelompok Penyelenggara Pemungutan Suara (KPPS), Panitia Pemilihan Kecamatan (PPK) atau Panitia Pemungutan Suara (PPS). Tujuannya adalah bekerja sama memanipulasi hasil penghitungan suara.

Apa yang terjadi dilapangan dan apa yang telah ditemukan oleh Edward Aspinall seharusnya menjadi bahan bagi KPU untuk memberikan pengetahuan lebih kepada pemilih pemula. Tanpa adanya pengetahuan yang jelas maka pemilih pemula tetap akan merasa bingung, karena kurangnya informasi yang didapat. Untuk itu, kedepannya KPU bisa menyiapkan bahan sosialisasi yang berpatokan pada pengalaman yang terjadi pada pemilu sebelumnya, juga memasukkan materi berdasarkan hasil penelitian yang telah dilakukan oleh akademisi.

SARAN

Seharusnya berdasarkan pengalaman Pemilu 2014, KPU sudah harus membedakan cara sosialisasi yang dilakukannya terhadap tingkatan dari pemilih tersebut. Dalam artikel ini penulis mengajukan agar KPU dalam melaksanakan sosialisasi tentang pendidikan kepada pemilih pemula memuat tentang kebutuhan dasar pemilih pemula itu sendiri, sebagaimana kita ketahui mereka kebanyakan belum memiliki pengalaman politik sehingga perlu bagi KPU dalam sosialisasinya membentuk pola pikir dengan basis rasionalitas untuk mempertimbangkan keputusan memilih atas dasar kemampuan, visi-misi dan mengetahui rekam jejak dari partai-partai dan kandidat. Sehingga mereka tidak bisa mudah dipengaruhi untuk menjual suara mereka. Dengan memberikan pengetahuan tentang seluk beluk pemilu maka akan menjadikan benteng pemahaman bagi mereka dalam mencerna sebuah informasi.

\section{Daftar Pustaka}

Aspinall Edward. 2014, When Brokers Betray: Clientelism, Social Networks, And Electoral Politics In Indonesia, Critical Asian Studies, 46(4): 545-570.

Irawan Ade,dkk.2014. Panduan Pemantauan KORUPSI PEMILU. Jakarta:ICW

Mewoh Ardiles R. M., dkk. 2015. Pemilu Dalam Perspektif Penyelenggara. Jakarta: Perludem

Putra Yanuar Surya.2016. Theoritical review : Teori perbedaan generasi. Jurnal Among Makarti. 9(18):123-124

Rahman, Asmika. 2017. Peran Sekolah Sebagai Sarana Sosialisasi Politik untuk Meningkatkan

Partisipasi Politik Pada Pemilih Pemula. Prosiding Konferensi

Nasional Kewarganegaraan III, Universitas Ahmad Dahlan, Yogyakarta 
NUSANTARA : Jurnal Ilmu Pengetahuan Sosial - Vol. 6 No 1 (2019) (Januari - Juni ) issn online : $2550-0813$ issn cetak : $2541-657 \mathrm{X}$

http://jurnal.um-tapsel.ac.id/index.php/nusantara

Rush, Michael \&Phillip Althoff. 2008.

Sosiologi Politik. Jakarta: Raja Grafindo Persada

Rusta Andri. 2015. Money Politics Dan Integritas Masyarakat Dalam Pemilihan Umum. PAHMI 9th International Conference Yogyakarta State University,

Subakti Ramlan, dkk. 2014. Integritas Pemilu 2014. Jakarta: Kemitraan.

Zed Mestika. 2004. Metode Penelitian Kepustakaan. Jakarta:Yayasan Obor Indonesia. Cetakan edisi kedua

https://acch.kpk.go.id/id/statistik/tinda k-pidana-korupsi

https://www.republika.co.id/berita/nas ional/politik/18/09/06/pelltj377-jpprpemilih-milenial-kunci-pemilu-2019berkualitas

https://www.merdeka.com/politik/inimodus-modus-makelar-jual-belisuara-dalam-pemilu.html

https://kpu-badungkab.go.id/bacaberita/642/Program-iGoesToSchooliKPU-Badung-Pertama-Ke-SMKPGRI-2-Badung.html

http://kotabukittinggi.kpu.go.id/2018/11/21/daringarai-sianok-kpu-bukittinggi-cetakmasyarakat-sadar-memilih/

http://kotabukittinggi.kpu.go.id/2018/10/26/perd alam-pengetahuan-untuk-jadi-pemilihmuda-cerdas/ http://kalsel.kpu.go.id/berita/kpu-goesto-school.html http://kotabukittinggi.kpu.go.id/2018/10/12/gene rasi-muda-agen-pemilih-cerdas/ 